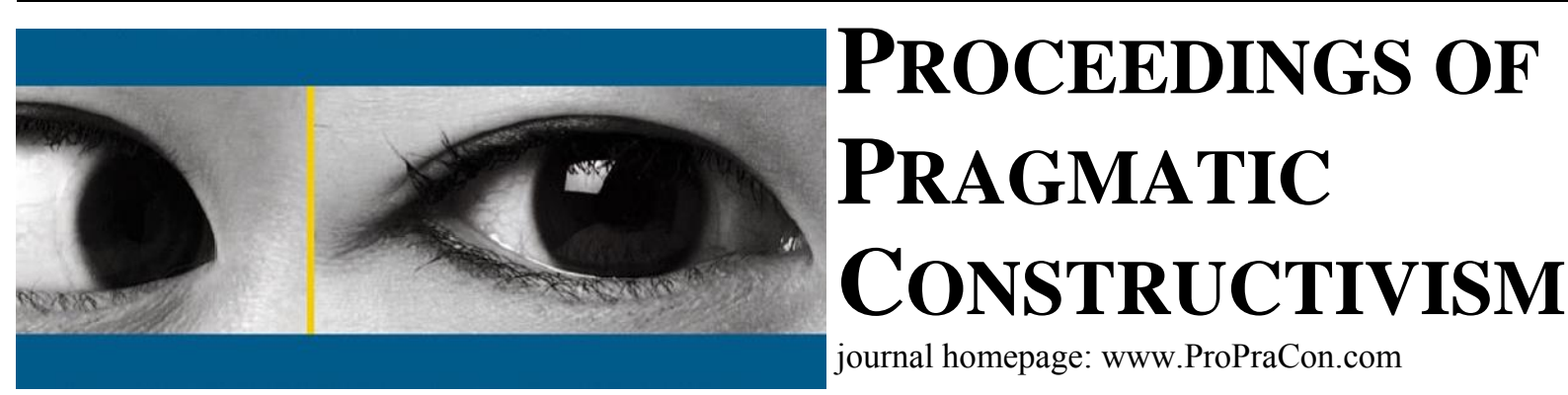

\title{
Managing individuality: myths versus art
}

\author{
Hanne Nørreklit \\ Professor of Management Control \\ Aarhus University; School of Business and Social Sciences; Department of Economics and Business \\ Fuglesangs Allé 4, 8210 Aarhus V, Denmark; hann@asb.dk
}

\begin{abstract}
The purpose of this article is to establish the symbolic forms that are presently used in selected mainstream management models and to assess whether the connection between leadership and individual human reality would be improved if the management models were fundamentally inspired by those used by a successful manager and artist.

The theoretical starting point of this article is Cassirer's (Cassirer 1999) philosophy of symbolic forms. A symbolic form is "a way of having a life world" (own translation) (Cassirer 1999). In a symbolic form, a person discovers and unfolds an ability to build his own universe as an ideal universe which enables the person to "understand and interpret, to articulate and organize, synthesize and universalize his human experience" (Cassirer 1962: 221). Symbolic forms such as art, science, myth and religion thus have common features and structures in their basic function of creating common human existence. When the symbolic form is science, ideals of objectivity and precision in the description of phenomena and their relations dominate man's formation of his universe. In art, man unfolds an ability to be subjective and create empathetic insight into matters and their diversity (Cassirer 1962). Where science as symbolic form conceptualizes objects, art teaches us empathetic insight. The symbolic forms of art and science perceive a phenomenon differently. For example, science will perhaps see a constellation as a trigonometric function, whereas it may be considered by art as a "Hogarthian shape of beauty" (own translation) (Cassirer 1999: 62). Like the symbolic form of art, the symbolic form of myth builds on emotional sympathy, but differs by believing in the existence of the constellation. It is used to create a natural or magical unity of life. Monotheistic religions also include ideas of striving for a sense of unity, but here the idea is to achieve a universal, ethical sense of unity in an individualized society. Thus the symbolic form of religion helps the individual to choose between right and wrong.
\end{abstract}

With this in mind, we examine the use of symbolic forms embedded in selected mainstream management models. Subsequently, we study the symbolic forms embedded in the management discourse as the concept is unfolded by the successful Artistic Director of the Royal Danish Opera, Kasper Holten, when he talks about management, with a view to determining the extent to which this practice differs from the symbolic forms embedded in the mainstream management models. The analysis shows that mainstream management models are primarily rooted in the symbolic form of science, although they tend to gradually include the symbolic form of religion or the symbolic form of myth. Generally speaking, the mainstream management models tend to exercise power over the individual's emphatic insight and autonomous reflection and thereby constrain the scope for human creativity and individuality. Distinctively, Kasper Holten's management discourse integrates the symbolic forms of art and science. With art as the dominant symbolic form, Kasper rejects new public management's perception about opera and the management of art while at the same time - through discourses that bind to the individuality of the network of players - forming personal and social identities which come together to realize a world of existential ideas about operas in general as well as opera in particular.

The article is relevant because it provides insight into the ways in which management models, through the use of myth and science as symbolic forms, exercise influence on human existence and interaction and thereby influence the scope for human freedom and exercise of power and also because it provides insight into the features and structures concerning human existence and co-existence from which mainstream management models cut themselves off by not using art as a form of consciousness. The constructive aspect is a parallel outline of features and structures in a new management discourse which are better suited for postmodern society. 


\title{
MANAGING INDIVIDUALITY \\ - MYTHS VERSUS ART
}

\author{
Hanne Nørreklit \\ Aarhus University, Denmark \\ hann@asb.dk
}

\section{Background and research area}

- Management discourse oppresses the individual person - the individual becomes an organization man (Ainsworth \& Hardy 2009; Alvesson \& Willmott 2002)

- What about business research approaches?

- Scientific

- Popular management

- What sort of 'individual' do these approaches construct or advocate?

- What if business researchers let themselves be inspired by a more artistic form? 


\section{Conceptual framework}

- Symbolic forms - Cassirer

- Science, art, myths and religion as symbolic forms are ideal universes -- ideal forms of social praxis

- A symbolic form is constituted by its specific genre, types of arguments and language use

- Symbolic forms are "a way of understanding and constructing a world"

\section{Discourse and symbolic forms}

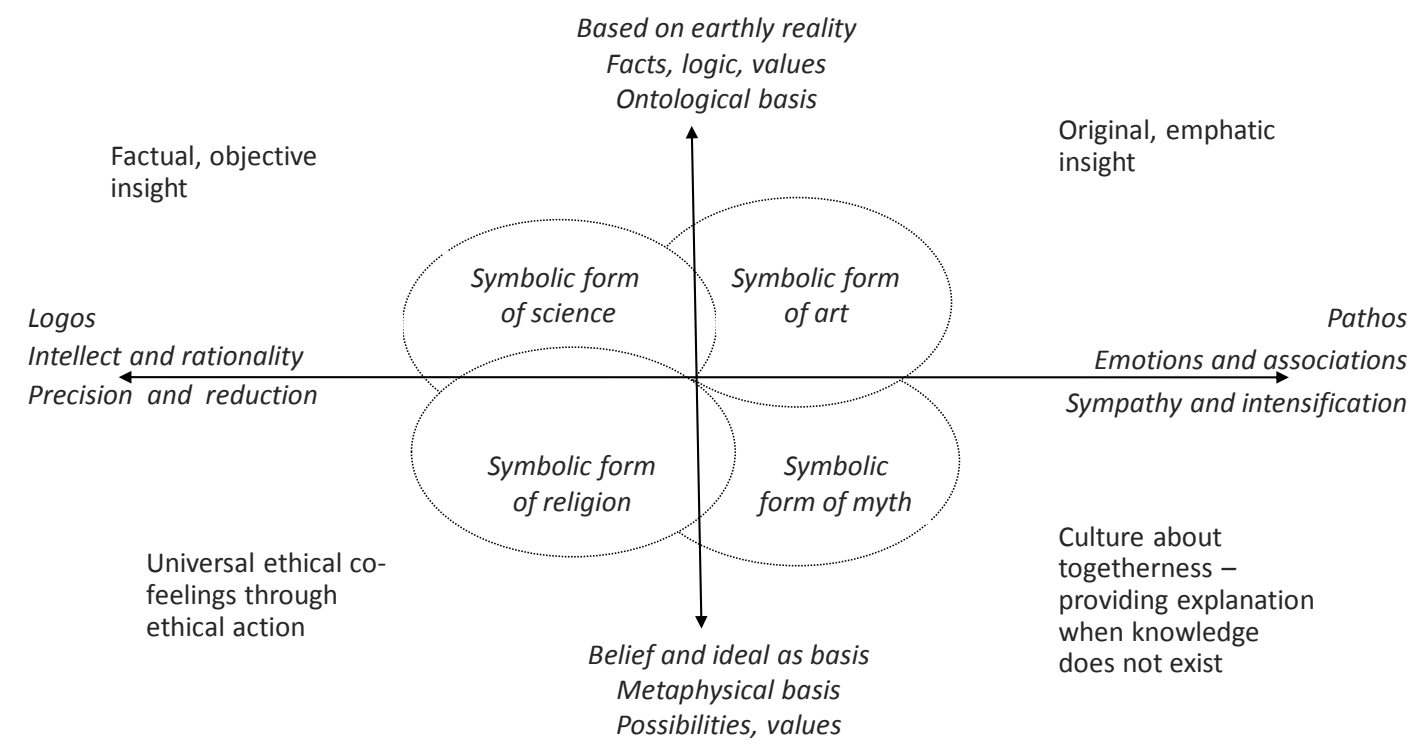




\section{Research question}

- Which symbolic forms are in use when describing and managing the individual person?

- Scientific approach

- Popular approach

- Kasper Holten's approach

- What are the implications for individuality ?

\section{Scientific approach}

- Precise and logical language

- Math

- Authority

- Rationalism

- Assumptions - rational economic man

- Logic - coherence

- Empiricism

- Factual evidence - quantitative generalization - statistical tests

- Assumed relationships???

- Rejects critique

- No rational economic man

- Failing models

- Symbolic form of religion

- Individuality oppressed 


\section{Popular management - Balanced scorecard}

- Language

- Heroic metaphors - the manager

- The pilot of a jet airplane

- The captain in a competitive race under changing weather and sea conditions

- Mechanical discourse - the management of the employees

- When A makes X in Z ways, B happens:

- Natural science lexis: Cause and effect, hypothesis test...

- $\quad$ Authority

- Kaplan and Norton/Harvard, Hall of fame ....

- Rejection of critique

- Fallacies and failing models

- The symbolic forms of myths

- A social praxis governed by a competitive macho togetherness

- Providing explanation where knowledge does not exist

- Oppresses individuality

\section{Implication of the ideal symbolic form of modernity}

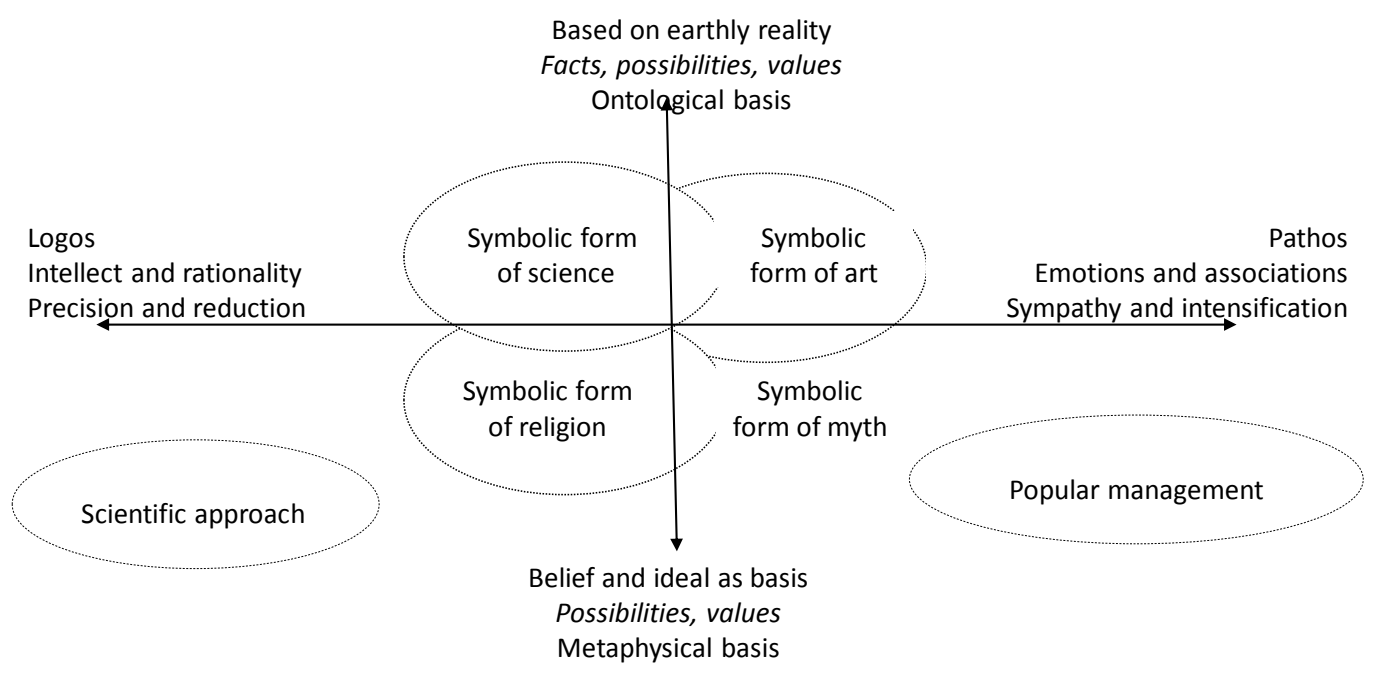




\section{The Royal Danish Opera's Artistic Director Kasper Holten}

- Very successful

- On management

- "with all the management tools I may have been given and which I have trained myself to use etc. etc. - they may be important enough - but at the end of the day, the only real management tool I have is my excitement, my enthusiasm, my love of opera and my ability to tell a story ...".

- Texts

- Speeches on management

- The Copenhagen Ring -- Directors Blog (2001-2006)

- Observation of his instruction of The Twilight of the Gods

- Planning

- Forming

- The idea of the Danish Royal Opera

- The opera production

\section{Forming the idea of the Danish Royal Opera}

...how does one measure a good opera performance? If we were to do the measuring, it would be one where people weep. The Danish Ministry of Finance would actually like us to include the measuring of good opera in our performance contract. I can easily imagine that if you designed a machine, I don't think you could, but say you could design a machine which could measure the quality of an opera performance, then on some evenings, I am sure it would say fantastic. Yes, but I would say, I didn't shed a single tear, and on other evenings it would say no, too many things went wrong, and she didn't sing the top C very well and I don't know what. And I must say that I cried inconsolably during her death scene. And I know which performance I would rather see. To measure the quality of an opera performance, we would have to install a hydrometer among the audience so as to be able to measure any increases in humidity. This is, of course, a bit affected, but this is a story which I can tell both to a stage technician who understands perfectly well that his wife cries her way through the dress rehearsal because it is so beautiful, and to a highly educated opera soloist who knows that when singing his death scene he really should do what he can to make the audience weep, and actually also to my secretary who must treat all the foreign agents so well that they send their best artists over here and unto the stage to make people weep. and those metaphors, that story, can be used throughout the house. 


\section{Forming the opera production: Figaro Narrative}

“.... if I do a performance where I just say that now you just do exactly as I say and please just shut up, then there won't be much commitment. What I mean is I usually use an example: let's say that I am staging the Marriage of Figaro. After all, the Marriage of Figaro is like Big Brother as an opera. You take 10 people who are all making a pass at each other and we sit and watch it for a couple of hours and nobody arrives and nobody leaves, that is all that is happening. If you are doing the Marriage of Figaro today, you may basically produce it as one of those sexual experiments, people making a pass at each other, how do erotic power balances define the relations between people, or you can do it as a story about rebellion, a servant rebelling against the count. It is about class war and revolution. If I were to stage Figaro today and I had decided to do it as a sexual experimentarium and I arrived on the first day of rehearsals and Figaro, the person singing Figaro, said, listen, I am really looking forward to doing Figaro, I have been reading about it and I have studied it, this part, and I have really come to grips with it. It is about revolution, isn't it, he is a revolutionary. Then I would have a problem as a manager as I cannot very well say to him, oh God, do you really think so, well, well, no, no, then we'll do that, let's do that. After all, the set has been built, and what if the countess arrives the next day and says quite the opposite, then what do I do? On the other hand, I cannot very well say to him, oh really, you have prepared for this part, you feel really involved in this project, please don't, please just forget everything you read at home, forget your own personal efforts, just forget what I say. For, of course, come the first night, it may be that Figaro goes on stage thinking, consciously or subconsciously, Kasper has done well before, I'll do what he says. It may be that he subconsciously feels that if only we had known what the right thing would be and therefore he does not sabotage the performance although he may still feel some resentment, but I promise you that by the 18th performance in November, when he arrives at the opera in the pouring rain just before the performance and he has just had a row with his wife and his daughter is ill and has just puked up on him and here he is, having to play the young lover, if he does not believe in this project then it can end up being quite a long evening for the audience, if you see what I mean. Of course he has to feel that it is his project, and therefore the casting of an actor or a singer is fundamentally about seducing them into believing that they had the good idea...."(Kasper Holten, speech on 28 September 2005)

\section{Forming the opera production Figaro Narrative}

- Language

- A reflective narrative form

- Creative language

- Logos

- A lot of different forces are present

- Multiple stories

- Get to know the singers

- Different methods to obtain results

- Interconnected stories

- It is Kasper who has to make it all come together

- Authority

- Human understanding - an emphatic insight in the experienced life

- Seduction based on a caring attitude 


\section{Forming the opera production Narrative on individual instructions}

- Appropriate and emphatic choice of stories and analogies

- Direction given to Gunther is: "And it is like when we men sit around at 5 o'clock in the morning",

- Humor and play:

- Well, boys and girls, we cannot talk our way out of it any longer, well maybe we can ... Boys, what are you doing to my assistant? Well, we cannot talk our way out of it any longer now. Boys on your marks

- We will play with that

\section{Conclusion Kasper}

- Symbolic form of art and science

- Reflective

- Emphatic insight in the phenomena (incl. human feelings)

- Human feelings and sympathy are involved

- Logos

- Obtains control (power) by story telling, integrating symbolic form of science and art

- Individuality (Caring philosophy, Levinas 1996)

- The individual's life-world is interconnected with the other person's lifeworld

- Caring for the other person's life-world, the opera, the audience and oneself

- Obtains control (power) by story telling, integrating symbolic forms of science and art 


\section{Opera discourse and ideal symbolic forms}

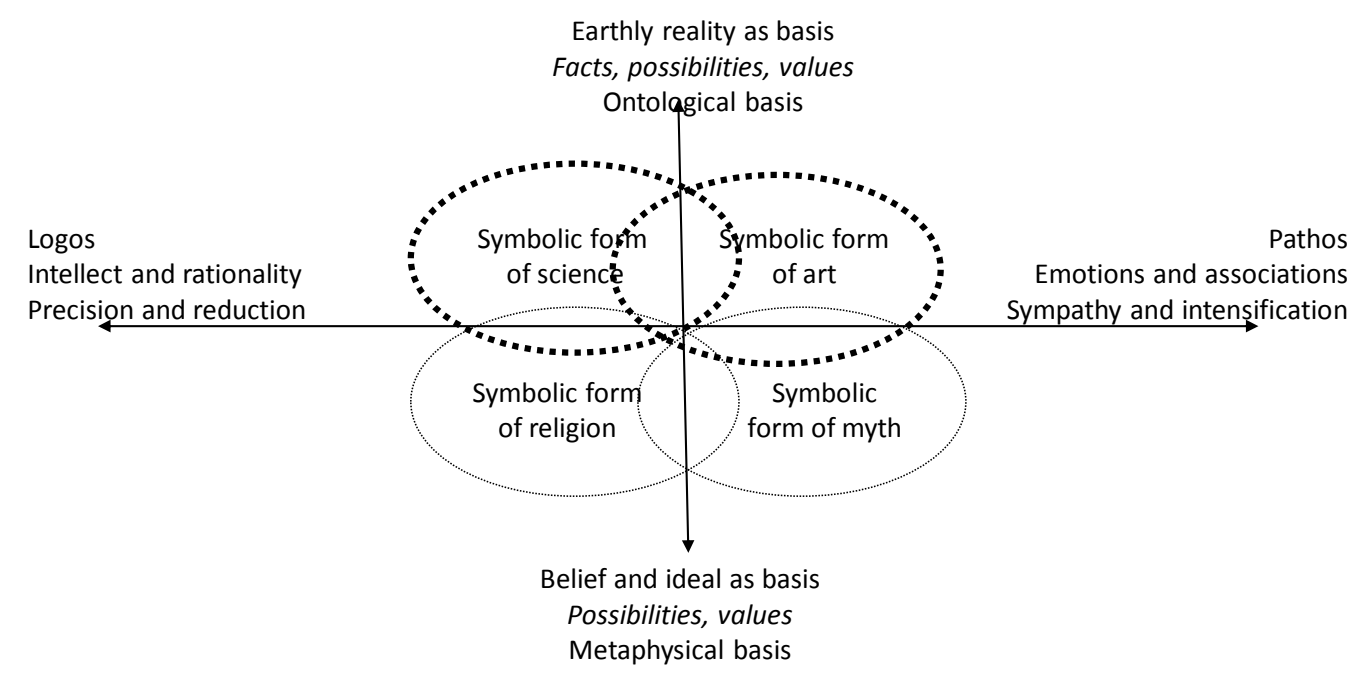

\section{Conclusion and perspectives}

- Prevailing research on management

- is trapped in the symbolic form of science

- oppresses individuality

- Kasper Holten

- has a more emphatic and hence more realistic language

- is capable of conceptualizing individuality

- Interpretive generalization

- Perspectives

- We need to develop more emphatic and hence realistic concepts

- Integrate symbolic forms of science and art 


\section{References}

Anthony, R. N. 1965. Planning and Control Systems. Boston, MA: Harvard Business Press.

Argyris, C., \& Schön, D. A. 1978. Organizational Learning: A Theory of Action Perspective. Reading, MA: AddisonWesley.

Cassirer, E. 1962. An Essay on Man. New Haven, CT: Yale University Press.

Cassirer, E. 1999. De Symbolske Formers Filosofi. Copenhagen: Gyldendahl.

Corbett, E. P., \& Connors, R. J. 1965. Classical Rhetoric for the Modern Student. New York, NY: Oxford University Press.

Fairclough, N. 1995. Media Discourse. Bristol: Edward Arnold.

Giddens, A. 1991. Modernity and Self-Identity. Cambridge: Polity Press.

Holten, K. B. 2006. The Copenhagen Ring - Hasper Bech Holtens Dagbog, available at www.old.kglteater.dk/blog/default.htm, accessed 1/3/2011.

Jensen, M. C., \& Meckling, W. H. 1976. Theory of the firm: managerial behavior, agency costs and ownership structure. Journal of Financial Economics, 3(4): 305-360.

Kaplan, R. S., \& Norton, D. P. 1996. The Balanced Scorecard: Translating Strategy into Action. Boston, MA: Harvard Business School Press.

Nørreklit, H. 2003. The balanced scorecard: what is the score? A rhetorical analysis of the balanced scorecard. Accounting, Organizations and Society, 28(6): 591-619.

Wittgenstein, L. 1922. Tractatus Logico-Philosophicus. London: Routledge and Kegan Paul. 